\title{
Descriptive study of intestinal parasites in a municipality of the western Brazilian
}

\author{
Amazon \\ Estudo descritivo de parasitoses intestinais em um município da Amazônia Ocidental Brasileira \\ Estudio descriptivo de parásitos intestinales en un municipio de la Amazonia Occidental Brasileña
}

Received: 10/05/2021 | Reviewed: 10/12/2021 | Accept: 10/14/2021| Published: 10/17/2021

\author{
Marcel Gonçalves Maciel \\ ORCID: https://orcid.org/0000-0003-2281-2934 \\ Universidade do Estado do Amazonas, Brazil \\ Corpo de Bombeiros Militar do Amazonas, Brazil \\ E-mail:mgmaciel@uea.edu.br \\ Walter dos Santos Lima \\ ORCID: https://orcid.org/0000-0002-1059-3589 \\ Universidade Federal de Minas Gerais, Brazil \\ E-mail: wlima@icb.ufmg.br \\ Djane Clarys Baia-da-Silva \\ ORCID: https://orcid.org/0000-0001-8726-3994 \\ Fundação de Medicina Tropical Dr Heitor Vieira Dourado, Brazil \\ E-mail: djane.claryss@gmail.com \\ Rodolfo Silva Moreira Cezar \\ ORCID: https://orcid.org/0000-0002-5366-3946 \\ Universidade Federal de Minas Gerais, Brazil \\ E-mail: rodolfocezar.mv@ @otmail.com \\ Josue Costa Oliveira \\ ORCID: https://orcid.org/0000-0001-8178-4633 \\ Fundação de Medicina Tropical Dr Heitor Vieira Dourado, Brazil \\ E-mail: jco0404@gmail.com \\ Gessica Cristian Raposo Medeiros \\ ORCID: https://orcid.org/0000-0002-8198-5627 \\ Universidade Paulista, Brazil \\ E-mail: gessicaraposomedeiros92@gmail.com \\ Marciane Gonçalves Maciel \\ ORCID: https://orcid.org/0000-0003-4867-3821 \\ Secretaria Municipal de Saúde de Guaíba, Brazil \\ E-mail: macielmarciane@gmail.com \\ Jorge Augusto de Oliveira Guerra \\ ORCID: https://orcid.org/0000-0002-4484-0402 \\ Fundação de Medicina Tropical Dr Heitor Vieira Dourado, Brazil \\ E-mail: jguerra291@gmail.com \\ Maria das Graças Vale Barbosa Guerra \\ ORCID: https://orcid.org/0000-0002-9579-0951 \\ Fundação de Medicina Tropical Dr Heitor Vieira Dourado, Brazil \\ Universidade do Estado do Amazonas, Brazil \\ E-mail:mgvale@uea.edu.br
}

\begin{abstract}
Intestinal parasites are among the most prevalent infections in humans. A cross-sectional survey was performed in a Canutama, Amazonas state, Brazil, in order to estimate the prevalence of intestinal parasites. The detection of parasites in the feces was performed using the Lutz method. Demographic data and the characteristics of the households were collected using a questionnaire. The prevalence of parasites was 36.9\%. Ascaris lumbricoides $(7.14 \%)$ was the most prevalent. The absence of a sewage network, consumption of raw vegetables and raw meat are risk factors for contracting intestinal parasitosis. We reported a prevalence of intestinal parasites and determined some of the risk factors.
\end{abstract}

Keywords: Protozoan infections; Helminthiasis; Ascaris lumbricoides.

\section{Resumo}

Parasitas intestinais estão entre as infecções mais prevalentes em humanos. Um estudo transversal foi realizado em Canutama, Estado do Amazonas, Brasil, para estimar a prevalência de parasitoses intestinais. A detecção de parasitas nas fezes foi realizada pelo método de Lutz. Os dados demográficos e as características dos domicílios foram coletados por meio de um questionário. A prevalência de parasitas foi de $36,9 \%$. Ascaris lumbricoides $(7,14 \%)$ foi o 
mais prevalente. A ausência de rede de esgoto, o consumo de vegetais crus e carne crua são fatores de risco para a contração de parasitoses intestinais. Nós relatamos uma prevalência de parasitas intestinais e determinamos alguns dos fatores de risco.

Palavras-chave: Infecções por protozoários; Helmintíase; Ascaris lumbricoides.

\section{Resumen}

Los parásitos intestinales se encuentran entre las infecciones más prevalentes en los seres humanos. Se realizó una encuesta transversal en Canutama, Estado de Amazonas, Brasil, con el fin de estimar la prevalencia de parásitos intestinales. La detección de parásitos en las heces se realizó mediante el método de Lutz. Los datos demográficos y las características de los hogares se recopilaron mediante un cuestionario. La prevalencia de parásitos fue del 36,9\%. Ascaris lumbricoides $(7,14 \%)$ fue el más prevalente. La ausencia de red de alcantarillado, el consumo de verduras crudas y carne cruda son factores de riesgo para contraer parasitosis intestinal. Informamos una prevalencia de parásitos intestinales y determinamos algunos de los factores de riesgo.

Palabras clave: Infecciones por protozoos; Helmintiasis; Ascaris lumbricoides.

\section{Introduction}

Intestinal parasitosis, which is caused by numerous protozoa and helminths, is among the most prevalent infections in humans and affects more than half of the world's population (WHO, 2020; De Silva et al., 2003). It occurs primarily among deprived populations around the world and causes significant morbidity and mortality in endemic countries. Almost 2 billion people (WHO, 2017; WHO, 2012) (about a quarter of the world's population) are infected with the variety that is transmitted through the soil.

Intestinal parasitosis has a wide geographic distribution in Brazil, and socioeconomic conditions, lack of basic sanitation, health education and cultural habits are some of the problems that cause enteroparasitosis to be highly common in Brazil (Faria et al., 2017). In the Amazon Region, enteroparasitosis is one of the main public health problems. In these regions, in the communities where basic sanitation conditions are precarious, there is no infrastructure for the adequate disposal of sanitary waste and little access to potable water (Martins et al., 2015).

In this study, we describe the prevalence of intestinal parasitosis in the habitants of the municipality of Canutama; a city located $55 \mathrm{~m}$ above sea level in the Purus region in the south of the Amazonas state, $620 \mathrm{~km}$ from the capital Manaus $\left(06^{\circ}\right.$ 32'19.7' S 064²3' 22.7' W) (Figure 1).

Figure 1: Localization of the municipality of Canutama, Amazonas state, Purus River, and distribution of the houses of the study participants.

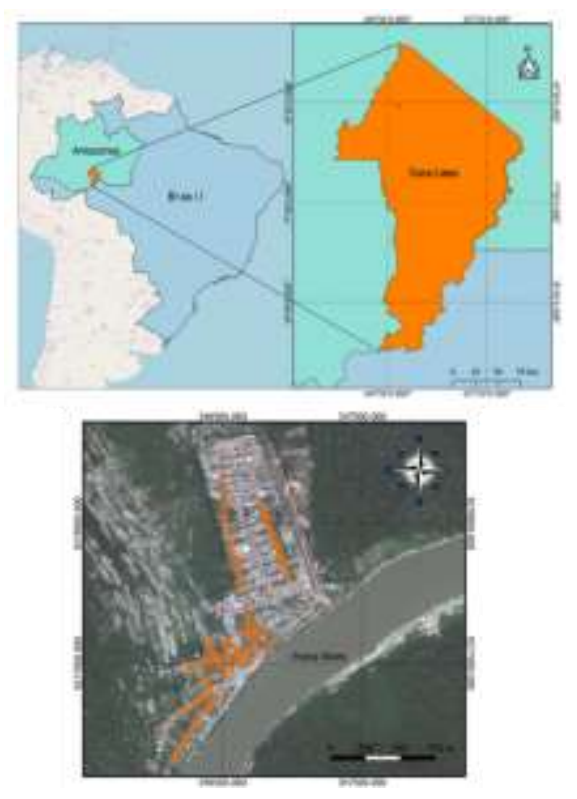

Source: Authors. 


\section{Methodology}

A cross-sectional coproparasitologic study was performed in the city in August, 2017, in which we selected sixty houses in the urban area. The sample size of the prevalence study was calculated according to Marciel et al., 2018 and a total of 434 participants were included in the study. All participants signed the informed consent form, and participants under 18 years of age were enrolled in the study only after authorization from their parents or legal guardians.

This study was approved by the Brazilian National Ethics Committee Board (approval number 319.463).

The detection of parasites in the feces was performed using the Lutz method (Lutz, 1919) and analyzed in the Municipal Clinical Analysis Laboratory of the Municipal Health Department of Canutama.

Demographic data and the characteristics of the households were collected using a questionnaire and these are described in Table 1. The data collected in the questionnaire were compiled and analyzed with the aid of the Epi Info program, version 6.04d.28 and statistical analysis was performed using Graph Pad Prism 7.0.

\section{Results}

We found a 36.9\% (160) prevalence of parasitosis (Table 2), which was distributed between $98(22.6 \%)$ females and $34(7.8 \%)$ males in the age group 40-59 years. A total of $28(6.4 \%)$ subjects reported having full secondary school education and $179(41.2 \%)$ stated "student" as their occupation.

Only one $(0.2 \%)$ person with parasitosis lived in a brick house and 159 (36.6\%) lived in wooden houses. Of the 434 participants, $12(2.8 \%)$ people with parasitosis did not have piped water, $160(36.9 \%)$ did not have mains water and $15(50.0 \%)$ store water in a bowl or bucket. In all, 159 (3.4\%) people with parasitosis had no sewage network and 101 (23.3\%) of these dumped their waste into streams, ditches, creeks, or rivers, while $59(13.6 \%)$ in cesspits. Only two residents $(0.4 \%)$ have animals in the peridomicile.

Regarding dietary habits, $142(32.7 \%)$ subjects admitted consumption of vegetables (such as lettuce, coriander and tomatoes) and 115 (26.5\%) raw meat. Non-binary logistic regression of the data regarding the absence of sewage network (OR $=0.2687, \mathrm{p}=0.0162)$, consumption of raw vegetables $(\mathrm{OR}=4.79, \mathrm{p}<0.0001)$ and raw meat $(\mathrm{OR}=1.612, \mathrm{p}<0.0284)$ shows these factors to be the highest potential risk factors for contracting intestinal parasites in Canutama (Table 1). 
Research, Society and Development, v. 10, n. 13, e420101321441, 2021

(CC BY 4.0) | ISSN 2525-3409 | DOI: http://dx.doi.org/10.33448/rsd-v10i13.21441

Table 1: Demographic and socioeconomic characteristics in the study population.

\begin{tabular}{|c|c|c|c|c|c|c|}
\hline Category/Subcategory & $\begin{array}{c}\text { Total } \\
\text { N }(\%)\end{array}$ & $\begin{array}{c}\text { No parasitoses } \\
\mathbf{N}(\%)\end{array}$ & $\begin{array}{c}\text { Parasitoses } \\
\text { N }(\%)\end{array}$ & $\begin{array}{l}\text { Odds } \\
\text { ratio }\end{array}$ & CI $(95 \%)$ & $P$ value \\
\hline \multicolumn{7}{|l|}{ Gender } \\
\hline Female & $260(60.2)$ & $160(62.3)$ & $100(37.7)$ & 0.92 & 0.61 to 1.35 & 0.69 \\
\hline Male & $174(40.3)$ & $111(64.4)$ & $63(35.6)$ & & & \\
\hline \multicolumn{7}{|l|}{ Age (years) } \\
\hline $0-19$ & $181(41.9)$ & $114(63.0)$ & $67(37.0)$ & & & 0.57 \\
\hline $20-39$ & $146(33.8)$ & $96(65.8)$ & $50(34.2)$ & & & \\
\hline $40-59$ & $78(18.1)$ & $44(56.4)$ & $34(43.6)$ & & & \\
\hline $60-79$ & $22(5.1)$ & $16(72.7)$ & $6(27.3)$ & & & \\
\hline$>70$ & $7(1.6)$ & $4(57.1)$ & $3(42.9)$ & & & \\
\hline \multicolumn{7}{|l|}{ Education } \\
\hline Illiterate & $107(24.8)$ & $66(61.7)$ & $41(38.3)$ & & & 0.52 \\
\hline Primary school & $258(59.7)$ & $167(64.7)$ & $91(35.3)$ & & & \\
\hline Secondary school & $67(15.5)$ & $39(58.2)$ & $28(41.8)$ & & & \\
\hline University & $2(0.5)$ & $2(100)$ & $0(0.0)$ & & & \\
\hline \multicolumn{7}{|l|}{ Occupation } \\
\hline Retired & $19(4.4)$ & $12(63.2)$ & $7(36.8)$ & & & 0.19 \\
\hline Civil servant & $17(3.9)$ & $11(64.7)$ & $6(35.3)$ & & & \\
\hline Student & $179(41.4)$ & $115(64.2)$ & $64(35.8)$ & & & \\
\hline Farmer & $70(16.2)$ & $49(70.0)$ & $21(30.0)$ & & & \\
\hline Fisher & $19(4.4)$ & $7(36.8)$ & $12(64.0)$ & & & \\
\hline Self-employed & $117(27.1)$ & $72(61.5)$ & $45(38.5)$ & & & \\
\hline Domestic & $13(3.0)$ & $8(61.5)$ & $5(28.5)$ & & & \\
\hline \multicolumn{7}{|l|}{ Type of housing and floor type } \\
\hline Brick & $1(0.2)$ & $0(0.0)$ & $1(100)$ & 0 & 0 to 5.25 & 0.37 \\
\hline Wood & $433(99,8)$ & $274(63.3)$ & $159(36.7)$ & & & \\
\hline \multicolumn{7}{|l|}{ Piped water } \\
\hline No & $26(6.0)$ & $14(53.8)$ & $12(46.2)$ & 1.50 & 0.67 to 3.2 & 0.40 \\
\hline Yes & $408(94.4)$ & $260(63.7)$ & $148(36.3)$ & & & \\
\hline \multicolumn{7}{|l|}{ Treated water } \\
\hline No & $434(100)$ & $274(63.1)$ & $160(36.9)$ & & & \\
\hline \multicolumn{7}{|l|}{ Water storage } \\
\hline Bowl/bucket & $30(6.9)$ & $15(50.0)$ & $15(50.0)$ & 2.04 & 0.96 to 4.32 & 0.07 \\
\hline \multicolumn{7}{|l|}{ Sewage network } \\
\hline No & $428(99.1)$ & $269(62.9)$ & $159(37.1)$ & 0.27 & 0.10 to 0.79 & 0.02 \\
\hline Yes & $6(0.9)$ & $5(83.3)$ & $11(6.7)$ & & & \\
\hline \multicolumn{7}{|l|}{ Sewage disposal } \\
\hline Stream, ditch, river and creek & $283(65.3)$ & $182(64.3)$ & $101(35.7)$ & 0.77 & 0.51 to 1.16 & 0.24 \\
\hline Cess pit & $141(34.7)$ & $82(58.2)$ & $59(41.8)$ & & & \\
\hline \multicolumn{7}{|l|}{ Animals in peridomicile } \\
\hline Cattle, sheep, goats, horses and pigs & $6(1.4)$ & $4(66.7)$ & $2(33.3)$ & 0.85 & 0.16 to 3.7 & $>0.9$ \\
\hline No & $428(98.6)$ & $270(63.1)$ & $158(36.9)$ & & & \\
\hline \multicolumn{7}{|l|}{ Consumption of raw vegetables } \\
\hline No & $120(27.8)$ & $102(85.0)$ & $18(15.0)$ & 4.79 & 2.756 to 8.26 & $<0.0001$ \\
\hline Yes & $310(71.8)$ & $168(54.2)$ & $142(45.8)$ & & & \\
\hline \multicolumn{7}{|l|}{ Raw meat consumption } \\
\hline No & $151(34.8)$ & $106(70.2)$ & $45(29.8)$ & 1.61 & 1.05 to 2.43 & 0.03 \\
\hline Yes & $283(65.2)$ & $168(59.4)$ & $115(40.6)$ & & & \\
\hline
\end{tabular}


The prevalence of monoparasitism was 110 (25.3\%) with 91 (21\%) cases of helminths and 19 (4.4\%) of protozoa. The prevalence of polyparasitism was $50(11.5 \%)$ with $31(7.1 \%)$ helminth-helminth and $19(4.3 \%)$ helminth-protozoan infections (Table 2).

The most prevalent helminths in monoparasitism were Ascaris lumbricoides (31/7.14\%), Ancylostoma sp. (28/6.45\%) and Trichuris trichiura (16/3.69\%), and the most common protozoa were Entamoeba hystolica/Entamoeba dispar (11/2.53\%) and Giardia lambia $(8 / 1.84 \%)$.

The most frequent associations between the helminths were A. lumbricoides + Ancylostoma sp. (13/3\%), A. lumbricoides + Taenia sp. (3/0.69\%) and A. lumbricoides + T. trichiura + Ancylostoma sp. (3/0.69\%) and the associations for helminths and protozoans were Ancylostoma sp. + E. hystolicalE. dispar + G. lambia (5/1.15\%), T. trichiura + G. lambia $(3 / 0.69 \%)$, T. trichiura + E. hystolicalE. dispar (3/0.69\%), A. lumbricoides + G. lambia (2/0.46\%), A. lumbricoides + E. hystolicalE. dispar (2/0.46\%) and Ancylostoma sp. + E. hystolica/E. dispar (2/0.46\%) (Table 2).

Table 2: Distribution of the population according to cases and prevalence of intestinal parasites.

\begin{tabular}{|c|c|c|}
\hline Parasitosis & $\begin{array}{l}\text { Number } \\
\text { of cases }\end{array}$ & $\begin{array}{c}\text { Prevalence } \\
(\%)\end{array}$ \\
\hline \multicolumn{3}{|l|}{ Monoparasitism } \\
\hline \multicolumn{3}{|l|}{ Helminths } \\
\hline Ascaris lumbricoides & 31 & $7.14 \%$ \\
\hline Ancylostoma sp. & 28 & $6.45 \%$ \\
\hline Trichuris trichiura & 16 & $3.69 \%$ \\
\hline Enterobius vermicularis & 8 & $1.84 \%$ \\
\hline Taenia sp. & 8 & $1.84 \%$ \\
\hline \multicolumn{3}{|l|}{ Protozoans } \\
\hline Entamoeba hystolica/E. dispar & 11 & $2.53 \%$ \\
\hline Giardia lambia & 8 & $1.84 \%$ \\
\hline \multirow{2}{*}{\multicolumn{3}{|c|}{$\begin{array}{l}\text { Poliparasistism } \\
\text { Helminth }+ \text { helminth }\end{array}$}} \\
\hline & & \\
\hline A. lumbricoides + Ancylostoma sp. & 13 & $3.00 \%$ \\
\hline A. lumbricoides + Taenia sp. & 3 & $0.69 \%$ \\
\hline A. lumbricoides + T. trichiura + Ancylostoma $\mathrm{sp}$. & 3 & $0.69 \%$ \\
\hline A. lumbricoides $+E$. vermicularis & 2 & $0.46 \%$ \\
\hline A. lumbricoides $+T$. trichiura & 2 & $0.46 \%$ \\
\hline T. trichiura + E. vermicularis & 2 & $0.46 \%$ \\
\hline T. trichiura + Ancylostoma sp. & 2 & $0.46 \%$ \\
\hline Ancylostoma sp. + E. vermicularis & 1 & $0.23 \%$ \\
\hline T. trichiura + Taenia $\mathrm{sp}$ & 1 & $0.23 \%$ \\
\hline T. trichiura + E. vermicularis & 1 & $0.23 \%$ \\
\hline A. lumbricoides + T. trichiura + Ancylostoma sp. + Taenia $\mathrm{sp}$. & 1 & $0.23 \%$ \\
\hline \multicolumn{3}{|l|}{ Helminth + protozoan } \\
\hline Ancylostoma sp. + E. hystolica/E. díspar + G. lambia & 5 & $1.15 \%$ \\
\hline T. trichiura + G. lambia & 3 & $0.92 \%$ \\
\hline T. trichiura + E. hystolica/E. dispar & 3 & $0.69 \%$ \\
\hline A. lumbricoides + G. lambia & 2 & $0.46 \%$ \\
\hline A. lumbricoides $+E$. hystolica/E. dispar & 2 & $0.46 \%$ \\
\hline Ancylostoma sp. + E. hystolica/E. dispar & 2 & $0.46 \%$ \\
\hline E. vermicularis + E. hystolica/E. dispar & 1 & $0.23 \%$ \\
\hline Ancylostoma sp. + E. vermicularis & 1 & $0.23 \%$ \\
\hline T. trichiura + Taenia sp. & 1 & $0.23 \%$ \\
\hline T. trichiura + E. vermicularis & 1 & $0.23 \%$ \\
\hline A. lumbricoides + T. trichiura + Ancylostoma sp. + Taenia sp. & 1 & $0.23 \%$ \\
\hline
\end{tabular}




\section{Discussion}

The results show a lower prevalence of intestinal parasitosis when compared to other studies carried out in the Amazon region. Martins et al. (2015), in a review of 48 publications on the prevalence of parasitosis in the state of Amazonas, found a high global prevalence of intestinal parasites regardless of the municipality or the characteristics of the areas and populations studied.

Our findings are also different from the findings of Oliveira et al. (2007) in their parasitological survey of feces in the urban area of Canutama, which was carried out from $21^{\text {st }}$ to $30^{\text {th }}$ May, 2005, and used a cross-sectional design. These authors found a prevalence of $66.8 \%$, which is about two times higher than the prevalence found in our study. However, in both studies, helminths were more prevalent than protozoans.

In these two studies, A. lumbricoides and Ancylostoma sp. were the most prevalent helminths, while E. histolytica/E. dispar was the most prevalent protozoans. Contrary to the study by Oliveira et al. (2007), no infections by Strongyloides stercoralis or Hymenolepis nana were observed, but E. vermicular and Taenia sp. infections were detected. Oliveira et al. (2007) observed the prevalence of 2\% Fasciola hepatica, as did we in a previous study (Maciel et al., 2018) that involved a serological survey of human fascioliasis in the same patients that constitute the population of this study, which shows the prevalence $(1.8 \%)$ of $F$. hepatica eggs in their feces. This, however, was evidenced in a single patient and after a second collection of feces.

Parasites such as A. lumbricoides, T. trichiura and Entamoeba spp. affect about one billion people worldwide in more than 150 countries and territories (WHO, 2017). In Brazil, these parasites have great geographic distribution and high prevalence. A study conducted by Hurtado-Guerrero et al. (1999) in the riverside population in Nova Olinda do Norte in the Amazonas state demonstrated that these parasites were the most common parasites among the elderly.

We observed a similar prevalence of this type of parasitosis in individuals in the 40-59 age range, with only a difference for the specific determination of Entamoeba, which was determined with E. coli. Interestingly, an earlier study conducted in Canutama, showed that children are the main segment of the population affected by enteroparasitosis (Oliveira $e t$ al., 2007).

Amoebiasis is the third leading cause of death from parasitic diseases worldwide, and its greatest impact is on the people of developing countries. The World Health Organization (2017) estimates that approximately 50 million people worldwide suffer from invasive amoebic infection each year, resulting in 40-100 thousand deaths annually. Various epidemiological studies have indicated that the prevalence of intestinal parasites was especially high in developing countries, although, in many of these, the environmental risk factors have not been clearly elucidated (Silva et al., 2003).

In this study, A. lumbricoides presented a higher prevalence when compared to other enteroparasites. In Brazil, coproparasitological surveys in other communities have shown that A. lumbricoides also occurs more frequently (Faria et al., 2017; Martins et al., 2015; Hurtado-Guerrero et al., 1999). The prevalence of A. lumbricoides in most of the participants is probably related to the biology of the parasite (WHO, 2017), which has resistant eggs, with good adhesion to surfaces, and these are important factors for transmission, since the eggs are able to remain in the environment for a long time.

About 2.6 billion people in the world lack adequate sanitation and a lack of sanitation contributes to about $10 \%$ of the global disease burden (WHO, 2012). This causes mainly diarrheal diseases and parasitosis, and the absence of a sewage network may be related to the deposition of feces in the soil (Montresor, 2020), which favors contamination of the soil and water sources nearby, thus perpetuating the life cycle of most intestinal parasites.

In this study, the absence of a sewage network, consumption of raw vegetables and raw meat are a risk factor for intestinal parasites in Canutama. The absence of adequate sanitary installations in the home is related to a higher occurrence of helminths, as confirmed in the study by Prado et al. (2003) and Belo et al. (2012). 
The transmission of intestinal parasites predominantly occurs via fecal-oral route, both by the ingestion of water and by the consumption of food (Silva et al., 2003) that has been contaminated with infective forms of the parasites, especially foods that are consumed raw, such as vegetables.

Several surveys in different parts of the world have shown that the vegetables can be agents for transmission of protozoan cysts and oocysts and helminths eggs and larvae (Adejumoke and Morenikeji, 2015). In the present investigation, a large part of the population has a habit of consuming raw vegetables (71.8\%) and raw meat (65.2\%) and this is an important factor in the contraction of parasites.

An earlier study by Oliveira et al. (2007) showed that the consumption of raw vegetables was not a common habit among the population of the municipality of Canutama (25.2\%). Food (vegetables or meat) normally becomes a potential source of human infection by contamination, during production, collection, transport and preparation or during processing, and the sources of zoonotic contamination are usually feces or fecal contamination of soil or water (Silva et al., 2003; Adejumoke and Morenikeji, 2015).

Eating raw or undercooked contaminated beef or pork is the primary risk factor for acquiring parasites, and these include the protozoans Toxoplasma gondii and Sarcocystis spp., and the helminths Trichinella spp. and Taenia spp. Consumption of raw or undercooked meat and/or visceral organs contaminated with cysticerci of Taenia solium and Taenia saginata cause taeniasis, while the ingestion of Taenia sp. eggs cause cysticercosis (Esteves et al., 2005).

Taeniasis and cysticercosis reduce the quality of life in the population and are responsible for high costs of diagnosis and treatment in infected individuals. Cysticercosis is one of the major public health problems in developing countries, and neurocysticercosis (Garcia et al., 2020) is considered the most common parasitic disease of the human nervous system.

In this investigation, $9.38 \%$ of participants had Taenia sp. eggs in their feces, which is a relatively high prevalence when compared to other inquiries (Esteves et al., 2005). However, diagnosis via the detection of eggs in the feces does not allow the identification of the Taenia species, and the scrutiny of proglotides is the most adequate form. The identification of the presence of the parasite in the patient and subsequent treatment (Posio, 2020) is of great importance, since it creates the possibility of breaking the transmission cycle of these diseases.

In addition, investigations that demonstrate the presence of taeniasis and/or neurocysticercosis are of great importance, since they may help to map the different areas affected and aid in the subsequent implementation of adequate sanitary measures (Garcia et al., 2020).

\section{Conclusions}

In conclusion, the prevalence of parasites was $36.9 \%$ and Ascaris lumbricoides $(7.14 \%)$ was the most prevalent. The absence of a sewage network, consumption of raw vegetables and meat were identified as the greatest risk factors for intestinal parasitosis in Canutama.

Knowledge of the prevalence of enteroparasites and the consequent implementation of basic sanitation measures, such as mains water supply, adequate sewerage, as well as sanitary and environmental education are necessary measures for the reduction of parasite infection via oral-fecal transmission, there is also a need for more comprehensive studies and mass treatment of the local population.

\section{Acknowledgments}

The authors would like to thank Francisco Lazaro Moreira de Almeida (SEMSA), Otaniel Lyra (SEMSA), Francisco das Chagas Almeida da Silva (ADAF), Raimundo Nonato Melo de Andrade (SUSAM), Jair Oliveira de Almeida (SUSAM), 
Jonas Xavier Leocádio (SEMSA), Paixao Sampaio da Costa (SUSAM) and Maria Eva de Oliveira Almeida (SEMSA) for their support.

\section{References}

Adejumoke, A. \& Morenikeji, O. (2015). Prevalence of intestinal parasites in vegetables sold in major markets in Ibadan city, south-west Nigeria. Glob J Pure Appl Sci, 21(1),7-12.

Belo, V. S., Oliveira, R. B., Fernandes, P. C., Nascimento, B. W. L., Fernandes, F. V., Castro, C. L. F., Santos, W. B., \& Silva, E. S. (2012). Fatores associados à ocorrência de parasitoses intestinais em uma população de crianças e adolescentes. Rev Paul Pediatr, 30(2), 195-201.

De Silva, N. R., Brooker, S., Hotez, P. J., Montresor, A., Engels, D., \& Savioli, L. (2003). Soil-transmitted helminth infections: updating the global picture. Trends Parasitol, 19(12), 547-51.

Esteves, F. M., Silva-Vergara, M. L., \& Carvalho, A. C. (2005). Inquérito epidemiológico sobre teníase em população do Programa Saúde da Família no município de Uberaba, MG [Epidemiologic survey of teniasis in Health and Family Program in Uberaba, MG]. Rev Soc Bras Med Trop, 38(6), 530-1.

Faria, C. P., Zanini, G. M., Dias, G. S., da Silva, S., de Freitas, M. B., Almendra, R., Santana, P., \& Sousa, M. D. (2017). Geospatial distribution of intestinal parasitic infections in Rio de Janeiro (Brazil) and its association with social determinants. PLoS Negl Trop Dis, 11(3), e0005445.

Garcia, H. H., Gonzalez, A. E., \& Gilman, R. H. (2020). Taenia solium Cysticercosis and Its Impact in Neurological Disease. Clin Microbiol Rev, 33(3), e00085-19.

Hurtado-Guerrero, A. F., Alencar, F. H., \& Hurtado-Guerrero, J. C. (2005). Ocorrência de enteroparasitas na população geronte de Nova Olinda do Norte Amazonas. Acta Amaz, 35, 487-490.

Jensen, P. K., Phuc, P. D., Konradsen, F., Klank, L. T., \& Dalsgaard, A. (2009). Survival of Ascaris eggs and hygienic quality of human excreta in Vietnamese composting latrines. Environ Health, 8, 57.

Lutz, A. O. (1919). Schistosomum mansoni, segundo observações feitas no Brazil. Memórias do Instituto Oswaldo Cruz, 11, $121-155$.

Maciel, M. G., Lima, W. S., de Almeida, F. L. M., Coelho, L. I. A. R. C., Araújo, G. A. N., Lima, M. G., Maciel, L. H. G., Pereira, C. A. J., Maciel, T. C. S., Guerra, J. A. O., Santana, R. A. G., \& Guerra, M. G. V. B. (2018). Cross-Sectional Serological Survey of Human Fascioliasis in Canutama Municipality in Western Amazon, Brazil. J Parasitol Res, 6823638.

Martins, M., Lacerda, M. V., Monteiro, W. M., Moura, M. A., Santos, E. C., Saraceni, V., \& Saraiva, M. G. (2015). Progression of the load of waterborne and intestinal parasitic diseases in the State of Amazonas. Rev Soc Bras Med Trop, 48(1), 42-54.

Monteiro, T. H., Chaves, T. S. S., Matos, H. J., Sofffiatti, N. F., Guimarães, R. J., Guimarães, L. H., Ventura, A. M., \& Machado, R. L. (2015). Basic sanitation, socioeconomic conditions, and degree of risk for the presence and maintenance of malaria in a low-transmission area in the Brazilian Amazon. Rev Soc Bras Med Trop, 48(5),573-9.

Montresor, A., Mupfasoni, D., Mikhailov, A., Mwinzi, P., Lucianez, A., Jamsheed, M., Gasimov, E., Warusavithana, S., Yajima, A., Bisoffi, Z., Buonfrate, D., Steinmann, P., Utzinger, J., Levecke, B., Vlaminck, J., Cools, P., Vercruysse, J., Cringoli, G., Rinaldi, L., Blouin, B., \& Gyorkos, T. W. (2020). The global progress of soil-transmitted helminthiases control in 2020 and World Health Organization targets for 2030. PLoS Negl Trop Dis, 14(8), e0008505.

Nyarango, R. M., Aloo, P. A., Kabiru, E. W., \& Nyanchongi, B. O. (2008). The risk of pathogenic intestinal parasite infections in Kisii Municipality, Kenya. BMC Public Health, 8, 237.

Oliveira, A. A., Nascimento, A., Santos, T. A. M., Carmo, G. M. I., Dimech, C. P. N., Alves, R. M. S., Malaspina, F. G., Garcia, M. H. O., Santos, D. A, Aguiar, G. P. R., Albuquerque, B. C., \& Carmo, E. H. (2007). Estudo da prevalência e fatores associados à fasciolose no Município de Canutama, Estado do Amazonas, Brasil. Epidemiologia e Serviços de Saúde, 16(4), 251-259.

Pozio, E. (2020). How globalization and climate change could affect foodborne parasites. Exp Parasitol, 107807.

Prado, M. S., Strina, A., Barreto, M. L., Oliveira-Assis, A. M., Paz, L. M., \& Cairncross, S. (2003). Risk factors for infection with Giardia duodenalis in preschool children in the city of Salvador, Brazil. Epidemiol Infect, 2, 899-906.

World Health Organization. (2017). Guideline: preventive chemotherapy to control soil-transmitted helminth infections in at-risk population groups. WHO. https://apps.who.int/iris/handle/10665/258983.

World Health Organization. (2012). Soil-transmitted helminthiases : eliminating as public health problem soil-transmitted helminthiases in children : progress report 2001-2010 and strategic plan 2011-2020. WHO. https://apps.who.int/iris/handle/10665/44804. 